\title{
Studi Deskriptif Kadar Kolestrol, Gula Darah dan Asam Urat \\ Berdasarkan Usia di Desa Bojong \\ Kabupaten Pekalongan
}

\section{Tri Sakti Wirotomo}

FIKES Universitas Muhammadiyah Pekajangan Pekalongan,email: trisakti.w@gmail,com

\begin{abstract}
Abstrak. Perubahan epidemiologi di Indonesia berakibat terjadi pergeseran pola penyakit dari penyakit infeksi menjadi penyakit degeneratif dan metabolik. Penyakit degneratif dan metabolik merupakan penyakit tidak menular yang berlangsung kronis karena kemunduran fungsi organ akibat proses penuaan maupun pola hidup. Beberapa penyakit degeneratif dan metabolik misalnya penyakit kardiovaskuler, diabetes mellitus, dan peningkatan asam urat. Penyakit ini dapat dicegah atau dikurangi angka kejadiannya dengan melakukan deteksi dini faktor-faktor yang berpengaruh. Penelitian ini bertujuan untuk mengetahui kadar kolesterol, kadar gula darah, dan kadar asam urat berdasar usia. Jenis penelitian kuantitatif, dilakukan studi observasional dengan metode penelitian potong lintang. Hasil penelitian menunjukkan terdapat peningkatan kadar kolesterol, peningkatan gula darah sewaktu, dan peningkatan asam urat dengan bertambahnya usia. Simpulan dari hasil penelitian ini adalah dengan bertambahnya usia, kadar kolesterol, gula darah dan asam urat meningkat.
\end{abstract}

Kata kunci : kolesterol, gula darah, asam urat, usia

\section{Descriptive Study of cholesterol, blood sugar and gout levels \\ Based on age in Bojong Village \\ Pekalongan Regency}

\begin{abstract}
Changes in epidemiology in Indonesia result in changes in the pattern of diseases from infectious diseases to degenerative and metabolic diseases. Degnerative and metabolic diseases are non-communicable diseases that occur chronic due to setbacks. Some degenerative and metabolic diseases such as cardiovascular disease, diabetes mellitus, and increased uric acid. This disease can be prevented or calculated the number of events by early detection of determining factors. The purpose of this study was to determine cholesterol levels, blood sugar levels, and uric acid levels based on age. This type of research is quantitative, observational studies using crosssectional research methods. Research Results Show Increased Sugar Levels, Increased Blood Sugar During, and Increased Gout with Increased Age. Conclusions from the results of this study are with increasing age, cholesterol levels, blood sugar and uric acid also increase.
\end{abstract}

Keywords: cholesterol, blood sugar, gout, age

\section{Pendahuluan}

Angka kejadian penyakit degeneratif maupun metabolik masih cukup tinggi dan masuk dalam 10 besar penyakit terbanyak pada tiga bulan pertama tahun 2018 di wilayah kerja Puskesmas Bojong 1 Kabupaten Pekalongan. Jumlah kasus terbanyak ke dua dari 10 besar penyakit tersebut adalah hipertensi primer/esensial, kemudian polyarthritis-unspecified di peringkat ketujuh dan non insulin dependent diabetes mellitus without complications di urutan sembilan. Angka kejadian tersebut mengalami penigkatan dibandingkan data tahun 2017 wilayah kerja Puskesmas

Bojong 1 Kabupaten Pekalongan, dimana hipertensi primer/esensial termasuk peringkat lima besar, polyarthritisunspecified peringkat enam, sedangkan non insulin dependent diabetes mellitus without complications tidak masuk dalam 10 besar penyakit.

Feryadi, Sulastri, dan Kadri (2014) menjelaskan bahwa hipertensi merupakan masalah kesehatan yang banyak dijumpai di masyarakat dan berkolerasi dengan penyakit lain. Banyak faktor penyebab terjadinya hipertensi salah satunya adalah gangguan profil lipid. Hasil penelitian Feryadi, Sulastri, dan Kadri menyatakan bahwa terdapat hubungan 
yang bermakna antara kadar kolesterol dan trigliserida dengan kejadian hipertensi $(p<$ $0,05: \mathrm{OR}=2,40$, trigliserida $\mathrm{p}<0,05 ; \mathrm{OR}=$ $2,49)$.

Kadar glukosa darah adalah tingkat gula di dalam darah, konsentrasi gula darah, atau tingkat glukosa serum diatur dengan ketat di dalam tubuh (Henrikson \& Bech-nielsen, 2009). Di dalam darah, kadar gula selalu fluktuatif bergantung pada asupan makanan. Kadar gula darah yang tinggi disebut hiperglikemia. Menurut Fox dan Kilvert (2010) faktor yang dapat mempengaruhi gula darah pada diabetes melitus yaitu kurag berolahraga, jumlah makanan yan dikonsumsi bertambah. Meningkatnya stress dan faktor emosi, cemas, pengetahuan diit diabetes melitus, pertambahan berat badan dan usia, serta dampak perawatan obat misalnya steroid.

Asam urat (gout) merupakan kelainan metabolisme yang dalam perkembangannya bermanifestasi terhadap peningkatan konsentrasi asm urat dalam serum yang dapat menyebabkan nyeri (Wirotomo, 2013). Penyakit asam urat merupakan penyakit yang ditandai dengan serangan mendadak dan berulang dari artritis yang sangat nyeri karea adanya endapan kristal monosodium urat, yang terkumpul di dalam sendi sebagai akibat tingginya kadar asam urat di dalam darah (Anjarwati 2010, h.79). Susanto (2013) menjelaskan bahwa setiap orang memiliki kadar asam urat didalam tubuhnya yang bermanfaat dalam regenerasi sel untuk peremajaan sel, namu kadar asam urat yang tinggi dapat menyebabkan suatu penyakit yang sering disebut dengan gout artritis atau lebih dikenal dengan asam urat. Daimartha dan Adnan (2014), menyebutkan penyebab produksi asam urat meningkat yaitu karena gangguan metabolisme purin bawaan (inborn error of purin metabolism), mengkonsumsi makanan yang berkadar purin tinggi, kurangnya pembuangan asam urat karena ketidakmampuan ginjal, , mengkonsumsi obat tertentu seperti pirazinamid, diuretic, beta bloker, salsilat, olahraga yang terlalu berat, mengkonsumsi alkohol dan kegemukan (obesitas).

\section{Metode}

Penelitian ini merupakan jenis penelitian kuantitatif yang dilakukan dengan studi observasional dengan metode penelitian potong lintang (cross sectional). Populasi dalam penelitian ini adalah masyarakat Kecamatan Bojong, Kabupaten Pekalongan. Teknik pengambilan sampel yang digunakan dalam penelitian ini adalah teknik non probability smpling dengan metode convenient sampling atau accidental sampling. Di sini masyarakat yang hadir dan ditemukan oleh peneliti diambil sebagai sampel.

Diperoleh responden pemeriksaan kolesterol sejumlah 85 subyek, responden pemeriksaan gula darah sejumlah 69 subyek, responden pemeriksaan asam urat sejumlah 79 subyek. Analisa data yang digunakan adalah analisa univariate berupa gambaran statistic deskriptif berupa karakteristik responden yaitu usia, hasil pengukuran kolesterol, gula darah, dan asam urat. Penyajian data disajikan menggunakan tabel distribusi frekuensi berupa persentase dan rata-rata.

Penelitian ini dilaksanakan pada tanggal 29 April 2018 di Balai Desa Wangn Dowo Kecamaatan Bojong Kabupaten Peklongan.

\section{Hasil Penelitian}

Penyajian data diawali dari data karakteristik responden yang meliputi usia. Penyajian data berikutnya adalah analisis univariat kadar kolesterol, gula darah dn asam urat.

\section{Karakteristik Responden}

a. Distribusi Karakteristik Responden Berdasarkan Usia pada Pengukuran Kolesterol.

Tabel 1.1 Distribusi responden berdasarkan usia pada pengukuran kolseterol (n:85)

\begin{tabular}{lccc}
\hline Karakteristik & & Frekuensi & $(\%)$ \\
\hline Usia & Remaja akhir (17-25 tahun) & 2 & 2,4 \\
& Dewasa awal (26-35 tahun) & 3 & 3,5
\end{tabular}




$\begin{array}{lcc}\text { Dewasa akhir (36-45 tahun) } & 25 & 29,5 \\ \text { Masa lansia awal (46-55 tahun) } & 32 & 37,6 \\ \text { Masa lansia akhir (56-65 tahun) } & 17 & 20 \\ \text { Masa manula ( } \geq 66 \text { tahun) } & 6 & 7\end{array}$

Pada tabel 1.1 dapat dilihat, paling sedikit usia responden yang berada pada usia remaja akhir, rentang usia paling banyak adalah 46-55 tahun yaitu sebesar 32 reponden $(37,6 \%)$.

b. Distribusi Karakteristik Responden Berdsarkan Usia pada Pengukuran Gula Darah

Tabel 1.2. Distribusi responden berdsarkan usia pada pengukuran gula darah (n:69)

\begin{tabular}{llcc}
\hline Karakteristik & Frekuensi & $(\%)$ \\
\hline Usia & Remaja akhir (17-25 tahun) & 2 & 3 \\
& Dewasa awal (26-35 tahun) & 2 & 3 \\
& Dewasa akhir (36-45 tahun) & 21 & 30 \\
Masa lansia awal (46-55 tahun) & 23 & 33,3 \\
& Masa lansia akhir (56-65 tahun) & 15 & 22 \\
& Masa manula ( $\geq 66$ tahun) & 6 & 8,7
\end{tabular}

Pada tabel 1.2 dapat dilihat, paling sedikit usia responden yang berada pada usia remaja akhir, rentang usia paling banyak adalah 46-55 tahun yaitu sebesar 23 reponden $(33,3 \%)$.

c. Distribusi Karakteristik Responden Berdasarkan Usia pada Pengukuran Asam Urat

Tabel 1.3. Distribusi responden berdasarkan usia pada pengukuran asma urat (n:79)

\begin{tabular}{llcc}
\hline Karakteristik & Frekuensi & $(\%)$ \\
\hline Usia & Remaja akhir (17-25 tahun) & 2 & 2,5 \\
& Dewasa awal (26-35 tahun) & 4 & 5 \\
& Dewasa akhir (36-45 tahun) & 22 & 27,5 \\
& Masa lansia awal (46-55 tahun) & 30 & 38 \\
Masa lansia akhir (56-65 tahun) & 14 & 18 \\
& Masa manula (> 66 tahun) & 7 & 9
\end{tabular}

Pada tabel 1.3 dapat dilihat, paling sedikit usia responden yang berada pada usia remaja akhir, rentang usia paling banyak adalah 46-55 tahun yaitu sebesar 30 reponden $(38 \%)$.

\section{Analisis Univariat}

a. Tabel berikut menggambarkan data dari variabel dari kadar kolesterol responden

Tabel 2.1 Hasil Pengukuran Kolesterol (n:85)

\begin{tabular}{llcc}
\hline Variabel & Usia & Frekuensi & $\begin{array}{c}\text { Rata-rata } \\
(\mathrm{mg} / \mathrm{dl})\end{array}$ \\
\hline Kolesterol & Remaja akhir (17-25 tahun) & 2 & 184 \\
& Dewasa awal (26-35 tahun) & 3 & 197 \\
& Dewasa akhir (36-45 tahun) & 25 & 226 \\
& Masa lansia awal (46-55 tahun) & 32 & 221,5 \\
& Masa lansia akhir (56-65 tahun) & 17 & 233 \\
& Masa manula ( $\geq 66$ tahun) & 6 & 226 \\
& & & \\
\hline
\end{tabular}

Pada tabel 2.1 dapat dilihat, ratarata kadar kolesterol responden paling rendah berada pada usia remaja akhir (1725 tahun), kadar kolesterol paling tinggi adalah masa lansia 56-65 tahun yaitu sebesar $233 \mathrm{mg} / \mathrm{dl}$.

Berdasarkan tabel 2.1 menunjukkan adanya peningkatan kadar kolesterol dari usia yang paling rendah (usia remaja akhir) dengan kadar kolesterol 184 mg/dl ke masa manula $(226 \mathrm{mg} / \mathrm{dl})$, dimana perubahannya cenderung naik, seperti yang tampak dalam diagram 2.1. di bawah ini.

Diagram 2.1. Hasil Pengukuran

Kolesterol (n: 85)

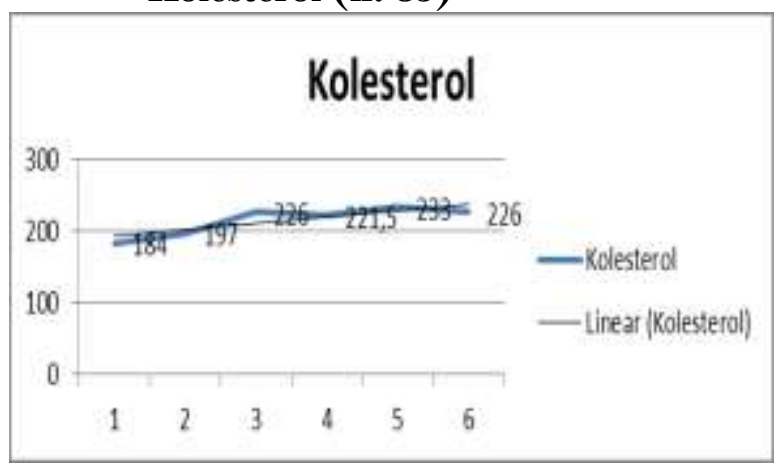

b. Kadar Gula Darah Sewaktu 
Tabel berikut menggambarkan kadar gula darah responden.

Tabel 2.2 Hasil Pengukuran Kadar Gula Darah (n:69)

\begin{tabular}{llcc}
\hline Variabel & Usia & Frekuensi & $\begin{array}{c}\text { Rata-rata } \\
(\mathrm{mg} / \mathrm{dl})\end{array}$ \\
\hline $\begin{array}{l}\text { Gula } \\
\text { Darah }\end{array}$ & Remaja akhir (17-25 tahun) & 2 & 96 \\
& Dewasa awal (26-35 tahun) & 3 & 135 \\
& Dewasa akhir (36-45 tahun) & 25 & 141 \\
& Masa lansia awal (46-55 tahun) & 32 & 168 \\
& Masa lansia akhir (56-65 tahun) & 17 & 124 \\
& Masa manula ( $\geq 66$ tahun) & 6 & 170,5
\end{tabular}

Pada tabel 2.2 dapat dilihat, ratarata kadar gula darah responden paling rendah berada pada usia remaja akhir (17-25 tahun), kadar kolesterol paling tinggi adalah masa manula $\geq 66$ tahun yaitu sebesar $170,5 \mathrm{mg} / \mathrm{dl}$.

Berdasarkan tabel 2.2 menunjukkan adanya peningkatan kadar gula darah dari usia yang paling rendah (usia remaja akhir) dengan kadar gula darah $96 \mathrm{mg} /$ dl ke masa manula (170,5 mg/dl), dimana perubahannya cenderung naik, seperti yang tampak dalam diagram 2.2 di bawah ini.

Diagram 2.2. Hasil Pengukuran Gula Darah (n: 69)

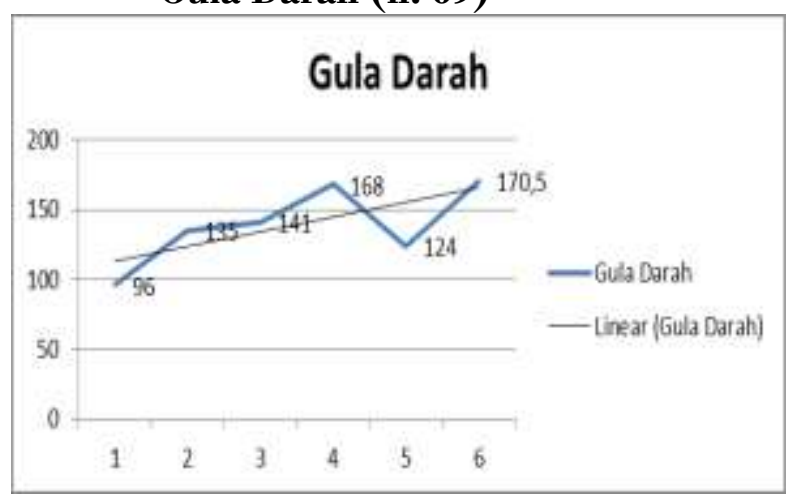

c. Kadar Asam Urat

Tabel berikut menggambarkan kadar asam urat responden.
Tabel 2.3 Hasil Pengukuran Asam Urat (n:79)

\begin{tabular}{llcc}
\hline Variabel & Usia & Frekuensi & $\begin{array}{c}\text { Rata-rata } \\
(\mathrm{mg} / \mathrm{dl})\end{array}$ \\
\hline $\begin{array}{l}\text { Asam } \\
\text { Urat }\end{array}$ & Remaja akhir (17-25 tahun) & 2 & 4,6 \\
& Dewasa awal (26-35 tahun) & 3 & 5 \\
& Dewasa akhir (36-45 tahun) & 25 & 4,5 \\
& Masa lansia awal (46-55 tahun) & 32 & 6,9 \\
& Masa lansia akhir (56-65 tahun) & 17 & 4,9 \\
& Masa manula ( $\geq 66$ tahun) & 6 & 7 \\
& & & \\
\hline
\end{tabular}

Pada tabel 2.3 dapat dilihat, ratarata kadar asam urat responden paling rendah berada pada usia dewasa akhir (36-45 tahun), kadar kolesterol paling tinggi adalah masa manula $\geq 66$ tahun yaitu sebesar 7 $\mathrm{mg} / \mathrm{dl}$.

Berdasarkan tabel 2.3 menunjukkan adanya peningkatan kadar gula darah dari usia yang paling rendah (usia remaja akhir) ke masa manula (7 $\mathrm{mg} / \mathrm{dl})$, dimana perubahannya cenderung naik, seperti yang tampak dalam diagram 2.3. di bawah ini.

\section{Diagram 2.3. Hasil Pengukuran Asam Urat (n: 79)}

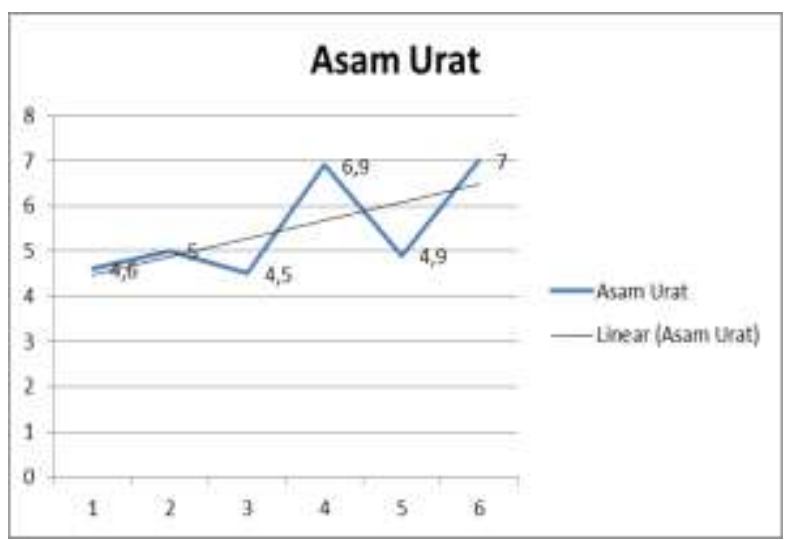

\section{Pembahasan}

Berdasarkan hasil penelitian, menunjukkan terdapat peningkatan kadar kolesterol dengan bertambahnya usia. Hasil ini 
berbeda dengan penelitian yang dilakukan oleh Ujani (2016) yang menyatakan bahwa tidak ada hubungan yang bermakna antara faktor usia dengan kolesterol, namun yang berhubungan adalah jenis kelamin. Perbedaan hasil ini dimungkinkan karena ada faktor lain yang menyebabkan peningkatan kadar kolesterol pada hasil penelitian, yang perlu diteliti lagi selain usia. Mulyani, Al Rahmad, dan Jannah (2018) menjelaskan bahwa kolesterol darah antara lain dipengaruhi oleh genetik, jenis kelamin, pola makan, obesitas, serta minum kopi berlebihan. Dimana konsumsi kopi terdapat hubungan yang signifikan dengan kadar kolesterol total pada penderita jantung koroner. Menurut Al Rahmad, Annaria, dan Fadjri (2016) terdapat resiko peningkatan kadar kolesterol pada kelompok usia $>3$ o tahun yaitu jenis kelamin, umur, keturunan dan IMT. Dimana jenis kelamin dan IMT merupakan prediktor dominan terhadap peningkatan kadar kolesterol.

Berdasarkan hasil penelitan menunjukkan terdapat peningkatan kadar gula darah sewaktu dengan bertambahnya usia. Hal ini senada dengan hasil penelitian Rudi dan Kwureh (2017) yang menyatakan ada hubungan antara umur dengan kadar gula darah puasa dengan $P$ value $=0,013 \leq 0,05$. Arief (2008) dalam Rudi dan Kwureh (2017) menjelaskan pendapat beberapa ahli bahwa dengan meningkatnya umur, maka intoleransi terhadap glukosa juga meningkat. Intoleransi glukosa pada lanjut usia sering dikaitkan dengan obesitas, aktivitas fisik yang kurang, berkurangnya masa otot, adanya penyakit penyerta dan penggunaan obat. Disamping itu pada lanjut usia sudah terjadi penurunan sekresi insulin dan resistensi insulin. Resiko terkena kadar gula darah akan meningkat sejalan dengan penuaan.

Berdasarkan hasil penelitian menunjukkan terdapat peningkatan kadar asam urat darah dengan bertambahnya usia. Hal ini sesuai dengan hasil penelitian Lioso,
Sondakh dan Ratag (2016), bahwa terdapat hubungan yang bermakna antara umur dengan kadar asam urat darah dengan nilai $p=0,001$.

\section{Simpulan}

Berdasar hasil penelitian dapat diambil simpulan yaitu terdapat peningkatan kadar kolesterol dengan bertambahnya usia, terdapat peningkatan kadar gula darah sewaktu dengan bertambahnya usia, terdapat peningkatan kadar asam urat dengan bertambahnya usia.

Saran yang dapat peneliti sampaikan dari hasil penelitian ini adalah agar responden dapat memodifikasi prediktor yang dapat diubah selain usia yang dapat meningkatkan kadar kolesterol, kadar gula darah, dan kadar asam urat.

\section{Daftar Pustaka}

Al-Rahmad, A. H., Annaria, A., \& Fadjri, T. K. Faktor Resiko Peningkatan Kolesterol pada Usia Diatas 30 Tahun di Kota Banda Aceh. Jurnal Nutrisia, 18(2), 109-114. 2016

Anjarwati, W. 2010. Tulang dan Tubuh Kita. Getar Hati. EGC. Jakarta

Dhaimartha. S dan Adnan. D. F. 2014. Tumbuhan Sakti Atasi Asam Urat. Jakarta: Penebar Swadaya.

Feryadi, R., Sulastri, D., Kadri, H. Hubungan kadar profil lipid dengan kejadian hipertensi pada masyarakat etnik Miangkabau di Kota Padang pada tahun 2012. Jurnal Kesehatan Andalas 3 (2), 2014

Fox, C., \& kilvert, A. (2010). Bersahabat dengan diabetes tipe 2. Depok: penebar plus.

Henrikson J. E., \& Bech- Nielsen H., (2009). Blood glucose levels. http:/www.netdoctor.co.uk/healthad vice/facts/diabetesbloodsugar.htm.

Lioso, J. P., Sondakh, R. C., \& Ratag, B. T. Hubungan Antara Umur, Jenis Kelamin Dan Indeks Massa Tubuh Dengan Kadar Asam Urat Darah Pada Masyarakat Yang Datang 
Berkunjung Di Puskesmas Paniki Bawah Kota Manado 2016.

Mulyani, N. S.,Al-Rahmad, A. H., Jannah, R. Faktor resiko kadar kolesterol darah pada pasien rawat jalan penderita jantung koroner di RSUD Meuraxa. ejournal.poltekkesaceh.ac.id 2018

Puskesmas Bojong 1 Kabupaten Pekalongan, Data 10 besar penyakit tahun 2017.

Susanto, Teguh. 2013. Asam Urat Deteksi Pencegahan, Pengobatan. Yogyakarta: Buku Pintar.

Wirotomo, T. S. Pengaruh Senam 10 Menit Terhadap Skala Nyeri pada Penderita Gout. Jurnal Ilmiah Kesehatan, 5(2). 2013

Ujani, S. Hubungan antara usia dan jenis kelamin dengan kadar kolesterol penderita obesitas rsud abdul moeloek provinsi lampung. Jurnal Kesehatan, 6(1) 2016 